\title{
INTERSTITIAL CELL TUMOR
}

\section{Profile of Hormone-Producing Tumor}

\author{
KARL R. HERWIG, M.D. \\ ROBERT K. VINSON, M.D. \\ From the Section of Urology, Department of Surgery, \\ University of Michigan Medical Center, \\ Ann Arbor, Michigan
}

\begin{abstract}
Interstitial cell tumor of the testis in an adult male can present with feminization and psychologic changes. The feminization and psychologic changes most likely reflect production of estrogen by the interstitial cell tumor. Removal of the tumor causes rapid return of the pituitarytesticular axis to normal, loss of feminization, and development of male psychosocial characteristics.
\end{abstract}

Interstitial cell tumors of the testes are rare. ${ }^{1}$ They affect two distinct age groups, prepubertal males and adults. In the prepubertal male, the tumor is usually associated with precocious puberty; in adults, it may be associated with feminization although the majority of adults have no evident endocrine disturbance. When feminization occurs, it is associated with psychologic change and abnormal hormone production.

\section{Case Report}

A twenty-six-year-old male was found to have an asymptomatic left testicular mass. He admitted to decreased libido and impotence and had undergone a reduction mammoplasty two years previously.

Physical examination revealed a welldeveloped male with normal escutcheon and secondary sex characteristics except for mild unilateral gynecomastia. A 1.5 by $1.5-\mathrm{cm}$. firm irregular mass occupied the upper pole of the left testis. A well-circumscribed tumor of the upper pole was found at time of orchiectomy. Histologically, the tumor was interpreted as a benign interstitial cell tumor with suppressed spermatogenesis at the secondary spermatocyte level in the remaining seminiferous tubules (Fig. 1).
Because of the gynecomastia, follicle stimulating hormone (FSH), luteinizing hormone (LH), and testostcrone levels were obtained before and after operation. In addition urinary estrogens, 17-hydroxycorticosteroids (17-OH) and 17-ketosteroids (17-KS) were measured postoperatively (Table I). Six months after removal of the tumor, the persistent elevation of urinary estrogens to pregnant levels prompted a thorough search for residual tumor but none was found. His hormone levels have returned to normal after two years.

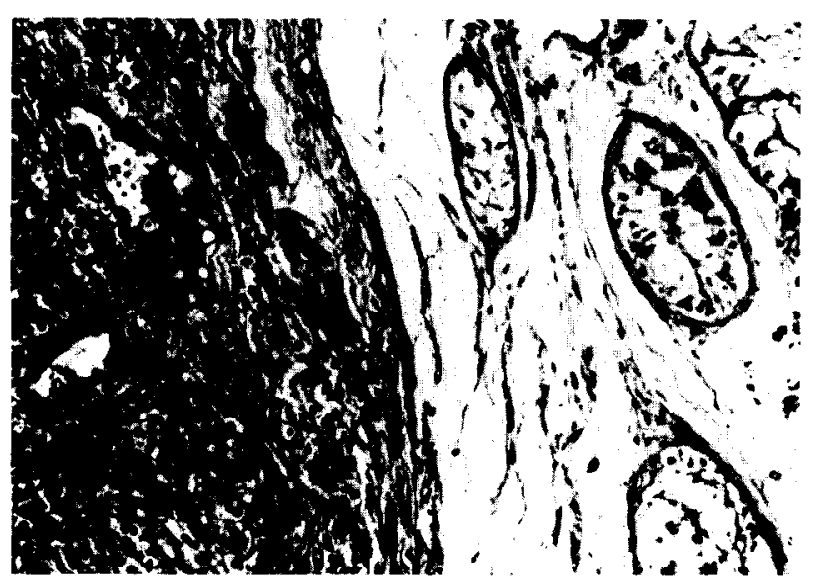

FIGURE 1. Microscopic appearance of interstitial cell tumor abutting seminiferous tubules. 
TABLE I. Endocrine determinations

\begin{tabular}{|c|c|c|c|c|c|c|c|}
\hline Laboratory Data & $\begin{array}{l}\text { Normal } \\
\text { Values }\end{array}$ & $\begin{array}{c}\text { Preoperative } \\
\text { Aug. } 10 \\
1973\end{array}$ & $\begin{array}{c}\text { Aug. } 14 \\
1973\end{array}$ & $\begin{array}{c}\text { Nov. } 28 \\
1973 \\
\end{array}$ & $\begin{array}{l}\text { April } \\
1974 \\
\end{array}$ & $\begin{array}{l}\text { May } \\
1974\end{array}$ & $\begin{array}{l}\text { April } \\
1976 \\
\end{array}$ \\
\hline Testosterone (ng./ml.) & $\begin{array}{r}5.99 \\
+2.02\end{array}$ & 2.42 & 5.91 & 10.2 & 6.85 & 9.7 & 7.16 \\
\hline FSH $(\mu \mathrm{g} . \mathrm{I} . \mathrm{U} . / \mathrm{ml})$. & $4-19$ & $<1.5$ & 30 & 22 & 16 & 16 & 17.8 \\
\hline LH $(\mu \mathrm{g} . \mathrm{I} . \mathrm{U} . / \mathrm{ml})$. & $5-20$ & 9 & 42 & 16.5 & 9 & 12 & 12.9 \\
\hline Total urinary estrogens (mg./24 hr.) & $4-25$ & - & 25.3 & 60 & 113 & 89 & 20.8 \\
\hline Estrone $\mathrm{E}_{1}(\mathrm{mg} . / 24 \mathrm{hr})$. & $3-8$ & - & - & 26.2 & 56.1 & 26.0 & 12.9 \\
\hline Estradiol $\mathrm{E}_{2}(\mathrm{mg} . / 24 \mathrm{hr})$. & $0-6$ & - & - & 11.6 & 23.6 & 22.6 & 14.0 \\
\hline Estriol $\mathrm{E}_{3}$ (mg./24 hr.) & $1-11$ & - & - & 21.4 & 33.4 & 31.1 & 9.6 \\
\hline $17-\mathrm{OH}$ (mg./24 hr.) & $5-10$ & - & 3.5 & 6.2 & 7.8 & 10.1 & - \\
\hline 17-KS (mg./24 hr.) & $6-20$ & - & 7.7 & 14.9 & 31.6 & 16.6 & - \\
\hline
\end{tabular}

Immediately after removal of the tumor, the patient's libido improved, potency returned, his personality became more aggressive, and gynecomastia was no longer evident.

\section{Comment}

Gynecomastia, impotence, and loss of libido in an adult are usually associated with an endocrine abnormality. In this patient, we postulate that estrogen or an estrogen-like substance was produced by the tumor severely depressing the pituitary testicular axis., ${ }^{2,3}$ The return of libido, potency, and personality change reflect return of this axis to normal postoperatively.

Despite the return of the pituitary-testicular axis to normal after an initial rebound, the urinary estrogens continued to rise although no evidence of residual tumor or symptoms of feminization were seen. We are unable to explain the source of these estrogens, but they could represent production of estrogen by the remaining testicle under the stimulus of FSH.

Histologically, the majority of interstitial cell tumors are benign. Only 15 cases of malignancy have been reported in the literature and have been found in men only over the age of thirty. ${ }^{4}$ The normal hormonal patterns and no evidence of tumor after three years support the diagnosis that this patient's tumor was benign.

Ann Arbor, Michigan 48109

(DR. HERWIG)

\section{References}

1. Jones WG, Onofrio $R$, and Goldstein AMB: Interstitial cell tumor of testes in adult, Urology 4: 459 (1974).

2. Gabrilove JL, Nicolis GL, Mitty HA, and Sohval AR: Feminizing interstitial cell tumor of the testes: personal observations and a review of the literature, Cancer 35: 1184 (1975).

3. Ances IG, et al: Case of feminizing interstitial cell tumor of the testicle, clinical and biochemical evaluation, J. Clin. Endocrinol. Metab. 33: 452 (1971).

4. Ober WB, Kabakow B, and Heckt H: Malignant interstitial cell tumor of the testis, Bull. N.Y. Acad. Med. 52: 561 (1976). 